\title{
Evaluation of the Scientific Reasoning Skills of 7th Grade Students in Science Course
}

\author{
Yurdagül Boğar \\ Department of Mathematics and Science Education, Faculty of Education, Hakkari University, Turkey
}

Copyright $\mathrm{C} 2019$ by authors, all rights reserved. Authors agree that this article remains permanently open access under the terms of the Creative Commons Attribution License 4.0 International License

\begin{abstract}
The aim of this study is to evaluate the scientific reasoning skills of middle school 7 th grade students in science course. The study group consists of 60 7 th grade students ( 35 females and 25 males) in a public school in the city center of Ankara. The research data were collected with seven questions, developed and applied once to the students by the researcher. The first five of these were two-stage questions and the last two were one-stage questions. According to the written answers of the students to these questions, a scoring rubric consisting of Level 0 , Level 1, Level 2 and Level 3 was developed by the researcher. After the rubric was developed by the researcher, the data were analyzed using descriptive analysis method. The findings of the study show that the reasoning performance of each 7th grade middle school student in the answers to the first two-stage five questions is considerably low ("Level 0"). It is thought that the results of this study may contribute to the studies of researchers, who are interested in argumentation and scientific reasoning skills in science education.
\end{abstract}

Keywords Scientific Reasoning Skills, Scientific Reasoning, 7th Grade Student, Science Course

\section{Introduction}

Current science education programs in the world and in Turkey aim to raise individuals, who can cope with real life problems, have the skills of discussion, questioning, decision making, are able to think scientifically and most importantly can reach the information themselves [25]. Therefore, today, science education programs focus on developing inquiry-based scientific thinking skills rather than developing students' memorization skills $[10,19,28$, $38,42,59]$. Contribution to the students' critical thinking skills, to the development of problem-solving skills and to making logical decisions are among the aims of science education. In this context; one of the aims of science education is to encourage students to participate in practices such as scientific reasoning [26].

In the literature, although not all the researchers agree on a common definition for the concept of scientific reasoning, different definitions by various researchers can be found. In other words, scientific reasoning is defined in different ways by different researchers. Hogan and Fisherkeller [18] described scientific reasoning as "the practice of thinking about scientific knowledge". According to Kuhn's [30] definition, scientific thought or scientific reasoning is a conscious and inherent social process. More specifically, it is an example of purposeful thinking which has the purpose of increasing the knowledge of the seeker (p. 372). Some researchers $[13,21,32,36,41,47,52]$ describe scientific reasoning by using the claim-evidence-reasoning framework. On the basis of this framework, "The claim is defined as the evidence supporting the question, the evidence as the data supporting the claim, and the reasoning as a link between the data and the claim".

Scientific reasoning is not a congenital, but a developing phenomenon through life. In other words, scientific reasoning skills are the skills that can be improved later in life [33]. For example, Vass and his colleagues [55] stated that effective science teaching could improve deficiencies in probabilistic, proportional and relational reasoning skills. Similarly, in their studies, Schwartz and her colleagues [49] stressed that the ability of pre-service teachers' scientific reasoning skills are enhanced when direct opportunity to reasoning and discussion, and sufficient time are provided. Furthermore, in order to facilitate the development of scientific reasoning skills, it is an undeniable fact that the nature, the interactions and the mechanisms that are based on these reasoning skills should be understood clearly.

The importance of scientific reasoning skills in science education has been stressed for a long time [40] because the scientific reasoning skills are extremely important for understanding and acquiring the rational aspect of scientific knowledge production process, making expressions in accordance with the scientific nature of scientific knowledge and gaining scientific discourse skills $[8,35]$. In addition, it has been demonstrated that scientific reasoning skills play an important role in the students' 
ability to develop a scientific understanding and to conduct scientific research [27, 34, 46, 48, 51]. Moreover, scientific reasoning skills are the key to success in academic and daily life [53, 57]. Furthermore, scientific reasoning skills include knowledge acquisition and conceptual change processes $[4,5,30]$. Therefore, scientific reasoning skills are indispensable in effective decision making and problem-solving processes [14, 17, 20, 43, 56]. Although acquiring scientific reasoning skills is an important learning objective, previous researches in science education show that students have insufficient scientific reasoning skills in terms of both academic and daily life [e.g., 1, 19, 31, 33, 44, 45, 48, 50, 54, 55, 58]. The students' lack of coordination of theory and evidence [30], their inability to fully achieve the cognitive, motivational and contextual interactions [19, 22, 45] and their consideration of their beliefs as definite truths [23] were mostly shown as the source of the deficiencies and inadequacies that they have about scientific reasoning. The deficiencies of students in conducting scientific reasoning revealed with these studies in the literature has disclosed the necessity of this study to be done in the context of Turkey. Also, in Turkey, most of the studies on scientific reasoning were carried out with university students or teacher candidates [e.g., 9, 24]. Studies with middle school students, especially with 7 th grade students, could not be found. The present study is important in this sense.

\subsection{Purpose of the Study}

In the literature, for the 7 th grade middle school students in science course, there is no study that attempts to determine the written scientific reasoning skills by a descriptive method, which is one of the quantitative methods, by creating a scoring rubric in Turkey. This study was planned with the assumption that the results obtained from such a research could contribute to the studies and literature in our country related to the subject and science education. The aim of this study is to evaluate the scientific reasoning skills of 7 th grade students in science course. With this purpose, the answer to the problem sentence given below has been sought:

1. What are the scientific reasoning skill levels of 7 th grade students in science course?

\section{Method}

In this study, with the aim of finding an answer to the research question "What are the scientific reasoning skill levels of 7 th grade students in science course?" descriptive research method, which is one of the quantitative research methods, was used as a method of study because the intention was to put the existing situation forward without intervention. Descriptive research method is defined by Büyüköztürk et al as a method that aims to describe a situation as it is [7].

\subsection{Study Group}

The study group consists of 607 th grade students (35 females and 25 males) in a public school in the city center of Ankara.

Table 1. 7th grade students' frequency and percentage values regarding gender

\begin{tabular}{lll}
\hline Gender & F & $\%$ \\
\hline Female & 35 & 58.33 \\
\hline Male & 25 & 41.67 \\
\hline
\end{tabular}

\subsection{Data Collection Procedure}

Data of the research have been collected with a seven-questions rubric developed by the researcher, which is one of the quantitative data collection tools and which was applied to the students once; the first five questions consisted of two-stages and the last two questions consisted of a one-stage. Rubrics are one of the most preferred data collection tools in revealing which information is known by the students to what degree, what the deficiencies are in the subject and the learning stages and in giving feedback to the students. According to Goodrich [12], it can be defined as a division of labor or scoring tool that lists the criteria for the measured property and lists what is expected from the student. In other words, rubrics are scoring designs that are developed under the guidance of teachers or other evaluators to analyze the students' studies and products. Rubrics have two types: holistic and analytical. A holistic rubric is used when the students' performances or a product is evaluated as a whole, and analytical rubric is used when students' performances or products are evaluated separately [3]. Since rubrics serve the purpose of evaluating high-level skills, they have become quite popular data acquisition tools in recent years [15]. These data collection tools allow students to develop high-level thinking skills [16]. In addition, the use of rubrics has many advantages for the practitioners (teachers or researchers) and students. These can be listed as follows:

- They enable the students to know what they are evaluated by and what the teacher wants from them.

- $\quad$ Since the students will know what they are evaluated by, they will not go beyond expectations so time will be saved during the teacher's evaluation.

- $\quad$ Significant feedback is supplied for the subjects in which the students are weak or strong.

- Individual and detailed feedbacks are provided.

- They provide objectivity because the evaluation criteria are certain.

- $\quad$ They provide objectivity for students in evaluating themselves or their peers.

- Students can follow their own developmental processes. 
- They encourage the teachers to be aware of the teaching methods they use, and to enable students to express their desired behaviors more clearly $[2,12$, 39].

In addition to the aforementioned advantages, there are some disadvantages or limitations of rubrics. These can be listed as follows:

- It may take a lot of time to prepare them as they require many preparatory processes and determining criteria.

- If the criteria are not determined well, the consistency between planners and reliability in return may diminish.

- Scoring with subjective criteria can also lead to time loss [6].

In this study, while the rubric was created by the researcher, the steps proposed by Goodrich [12] were used. These steps are: 1) Determining the criteria to be used in performance determination, 2) Determining the type of the scoring rubric to be used, 3) Determining the performance levels and making the level definitions, and finally 4) Obtaining expert opinion. Seven questions on the rubric prepared by considering these steps are as follows: In the first question, the students were asked this question by the researcher in written form: "Yigit tries to push the table in the study room. But he cannot move the table. In this case, which of the following statements is correct?" and they were asked to choose one of the multiple choices from A to $\mathrm{D}$. Then as the second part of the question, it was requested to "Explain the reason for your answer". In the second written question, the students were asked: "Which of the following statements regarding energy is correct?" and they were asked to choose one of the multiple choices from A to D. As the second part of this question, the students were asked to elaborate on their answers with the statement "Explain the reason for your answer". In the third question, the students were asked the following question: "Which of the following expressions about friction force is wrong?" this was a question for which the students were asked to choose one of the multiple-choice answers from A to D. The second part of the question was "Explain the reason for your answer". In the fourth question, the answer to the question "Kerem stretches the bow he has been given by the teacher in his science course. In this case, which of the following statements regarding the forces affecting the bow and Kerem is correct?" was asked and the students were to choose one of the multiple choices from A to D. The second part of this question was again "Explain the reason for your answer". In the fifth question, "Which of the following statement/statements is/are among the reasons why the electrical installations of the houses are installed in parallel?" was asked and the students were asked to choose one of the multiple choices from A to D, and then, "Explain the reason for your answer" was the second part of the question. The sixth written question was "In daily life, you hear a crackling sound when taking your sweater or shirt off. The reason for this phenomenon is the electrification of the objects. Why and how does this electrification event occur?". In the seventh and last question, the students were asked this question: "Based on scientific data, explain how electricity is formed, its structure and how it circulates in the electrical circuit by drawing a simple electrical circuit". The researcher collected the data in the first five questions by asking written questions consisting of two stages. In the sixth and seventh question, the researcher collected the data by asking written questions consisting of one stage.

\subsection{Data Analysis Procedure}

After the seven questions asked to reveal the students' scientific reasoning skills, according to the answers given by the students to these questions, a scoring rubric consisting of Level 0, Level 1, Level 2 and Level 3 was developed by the researcher. While developing the scoring rubric, the researcher benefitted from both foreign and domestic expert opinions, and at the same time, the scoring rubric was created by taking the scientific explanations in the foreign literature as the basis. The most important reason for it to be based on foreign literature is the absence of a scoring rubric developed on scientific reasoning skills at 7 th grade level in Turkey. Some criteria were taken into consideration while creating the scoring rubric (Level 0 , Level 1, Level 2, Level 3). At the level graded "Level 0", the students either left the answer section of the question blank by not explaining anything or made irrelevant explanations. At the level graded "Level 1", the students tried to explain their opinions about the question, but their efforts were inadequate. At the level graded "Level 2", explanations of the students regarding the question were reasonable and relevant to the question, yet they could not explain it exactly. At the level graded "Level 3", the students' answers for the questions were fully clear, relevant and reasonable. While creating the rubric according to these criteria, two Turkish teachers and three field experts were consulted for the validity of the rubric. Moreover, to ensure the reliability of rubric, the rubric was sent to four different researchers independent from each other and the results that came from them were evaluated, the percentage of consistency of the results of researchers' evaluation [the formula of Reliability = Opinion Alliance/Opinion Alliance + Opinion Separation X 100] was calculated and it was found as $92 \%$. The reliability formula recommended by Miles and Huberman [37] was used for the reliability measurement of the research. After the rubric was created by the researcher, descriptive statistics were used to analyze the data to evaluate students' scientific reasoning skills. Data were analyzed by using SPSS (Statistical Package for Social Sciences) package program. 


\section{Findings}

The general statistical results of this study are shown in Figure 1. The results in Figure 1 show that each 7 th grade middle school students' reasoning performances in the answers to the first five two-stage questions are considerably low ("Level 0"). Students with scientific reasoning skills at level 0 have either answered the questions incorrectly or made irrelevant explanations. Another important result is that we can say that the middle school students perform relatively better than the other six questions only in the seventh question (in the last question) and they are at "Level 2" for this question. Although most of the explanations of the students whose scientific reasoning performances were at "Level 2" were clear and relevant to the question, they did not explain the question completely scientifically. One of the most striking results of the study is that all the students are at "Level 0" for the second question. This result indicates that the second question is the most challenging question while the students were carrying out scientific reasoning.

\subsection{Findings of Scientific Reasoning Skills of the Students in the First Question}

In the first question, the students were asked the following question: "Yigit tries to push the table in the study room, but he can't move the table. In this case, which of the following statements is correct?" and they were asked to choose one of the multiple choices from A to $\mathrm{D}$; then, as the second part of the question, they were asked to explain their answers with the statement "Explain the reason for your answer". The findings are shown in Figure 2. According to Figure 2, in this question, $87 \%$ of the students are at level $0,5 \%$ of them are at level 1 , $7 \%$ of them are at level 2 and about $1 \%$ of them is at level 3.

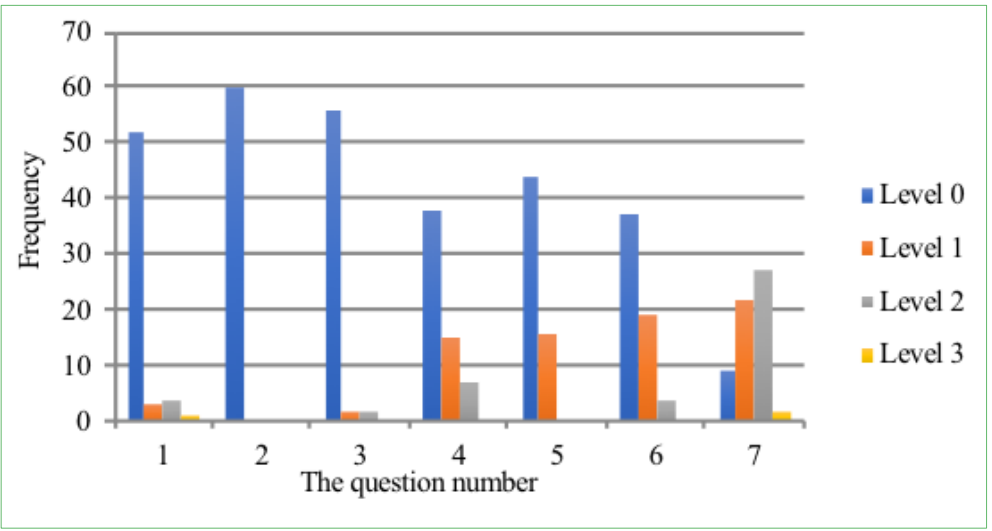

Figure 1. Scientific reasoning performances of students for seven questions

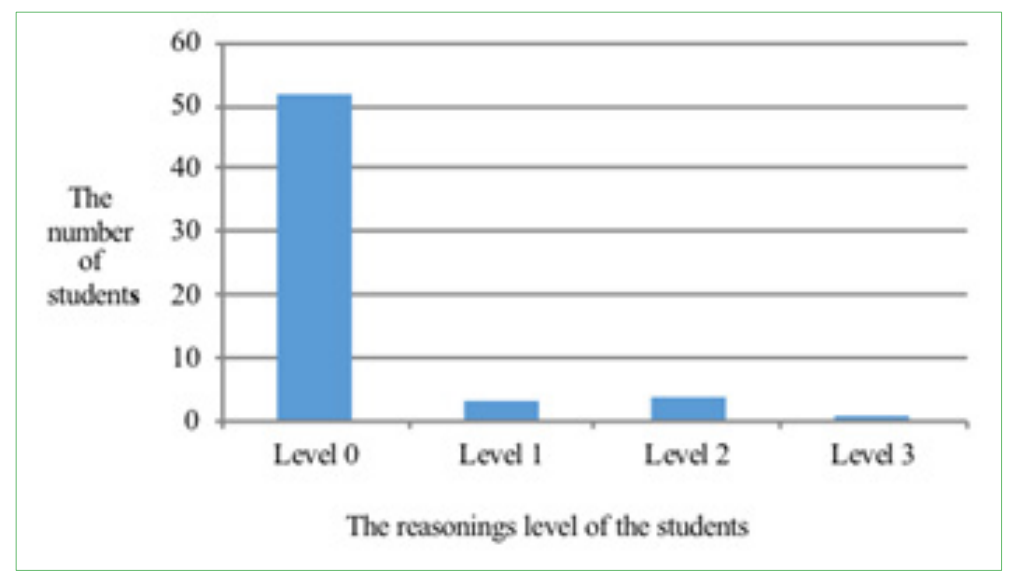

Figure 2. Scientific reasoning performance of students for the first question

Table 2. A student's answers to the first question and levels of reasoning

\begin{tabular}{lll}
\hline Question 1 & Example Answer & Reasoning Level \\
\hline & Because Yiğit does not move the table, the force does not affect Yiğit and the table. & Level 0 \\
& $\begin{array}{l}\text { The force affects Yiğit but does not affect the table. I think it's the effect of friction force. He } \\
\text { uses kinetic energy as he pushes the table. }\end{array}$ \\
\hline $\begin{array}{l}\text { Because Yiğit is trying to push the table, but he cannot push. Thus, Yiğit applies force to the } \\
\text { table; the table also applies force to Yiğit. }\end{array}$ & Level 2 \\
\hline Because Yiğit's force is equal to the force of the table, it does not move. & Level 3 \\
\hline
\end{tabular}




\subsection{Findings of Scientific Reasoning Skills of the Students in the Second Question}

In the second written question, the students were asked that the question "Which of the following statement/statements regarding energy is correct?" and requested to choose one of the multiple choices from A to D. The second part of the question was "Explain the reason for your answer". The findings are shown in Figure 3. According to Figure 3, all students are at "level 0" for this question. Based on this finding, we can say that in the second question, all students have difficulty in scientific reasoning.

\subsection{Findings of Scientific Reasoning Skills of the Students in the Third Question}

In the third question, the question that was asked was "Which of the following expressions about friction force is wrong?" and the students were asked to choose one of the multiple choices from A to D. Then, as the second part of the question, the students were asked to explain their answers with the statement "Explain the reason for your answer". The findings of this question are shown in Figure 4. According to Figure 4, in this question, $93 \%$ of the students are at level $0,3.5 \%$ of them are at level 1 and $3.5 \%$ of them at level 2. There are no students at level 3 in this question.

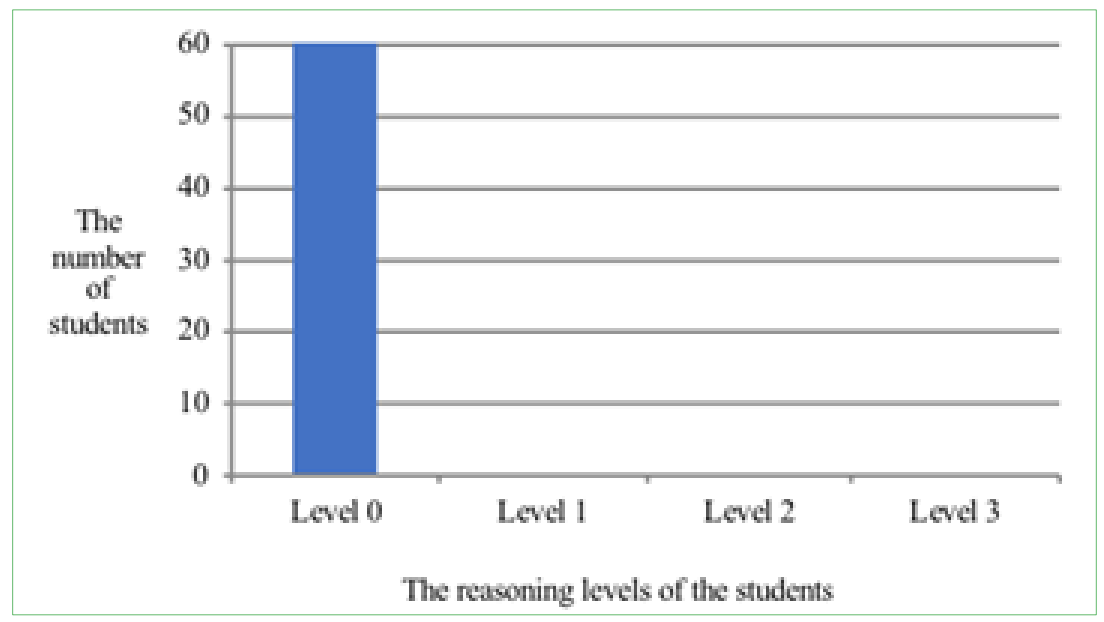

Figure 3. Scientific reasoning performance of students for the second question

Table 3. A student's answers to the second question and levels of reasoning

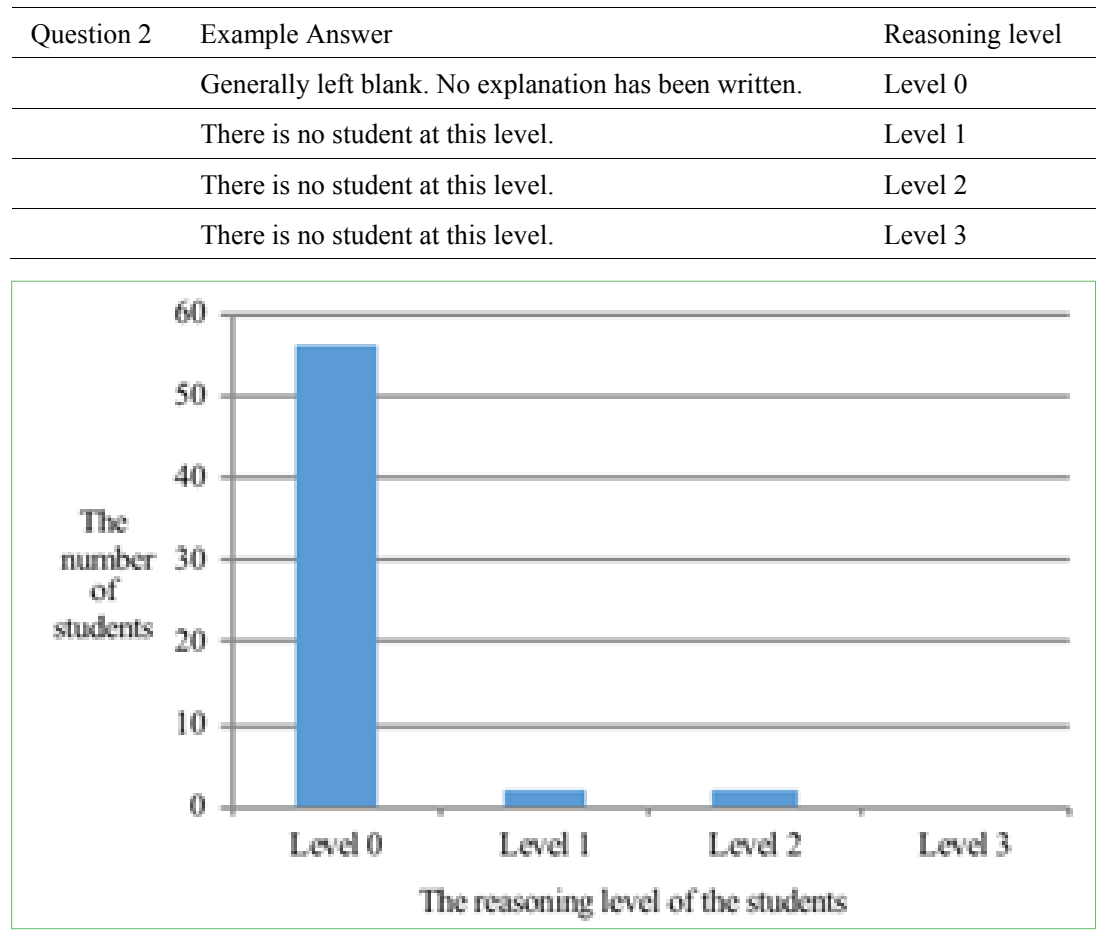

Figure 4. Scientific reasoning performance of students for the third question 
Table 4. A student's answers to the third question and levels of reasoning

\begin{tabular}{llc}
\hline $\begin{array}{l}\text { Question } \\
3\end{array}$ & Example Answer & $\begin{array}{l}\text { Reasoning } \\
\text { level }\end{array}$ \\
\hline & $\begin{array}{l}\text { The friction force depends on the type of the friction surface. For example, the friction force applied by an } \\
\text { ice or a wooden surface on an object on that surface is different. }\end{array}$ & Level 0 \\
\hline $\begin{array}{l}\text { When something is rubbed against an object standing toward the others, the frictional force occurs again. } \\
\text { Frictional force also affects non-moving objects. If a cabinet does not touch the ground, it will not stand in } \\
\text { place and fall. That's why A. }\end{array}$ & Level 1 \\
\hline There is no student at this level. & Level 2 \\
\hline
\end{tabular}

\subsection{Findings of Scientific Reasoning Skills of the Students in the Fourth Question}

In the fourth question given in written form, the students were asked the following question: "Kerem stretches the bow he has been given by the teacher in his science course. In this case, which of the following statements regarding the forces affecting the bow and Kerem is correct?". The answer for this question was to be chosen from multiple choices from A to D. "Explain the reason for your answer" statement constituted the second part of this question. The statistical findings of this question are shown in Figure 5. According to the findings in Figure 5, in this question, $63.5 \%$ of the students are at level $0,25 \%$ of them are at level 1 and $11.5 \%$ of them are at level 2 . There are no students at level 3 in this question.

\subsection{Findings of Scientific Reasoning Skills of the Students in the Fifth Question}

In the fifth written question, the first part of the question was "Which of the following statement/statements is/are among the reasons why the electrical installations of the houses are installed in parallel?" and the students were asked to choose one of the multiple choices from A to D. Then as the second part of the question, the students were asked to elaborate on their reasoning for the answer with the statement "Explain the reason for your answer". The statistical findings of this question are shown in Figure 6. According to the findings of Figure 6,73.3\% of the students are at level 0 for this question and $26.7 \%$ of them are at level 1 . In this question, there are no students carrying out scientific reasoning at level 2 and level 3.

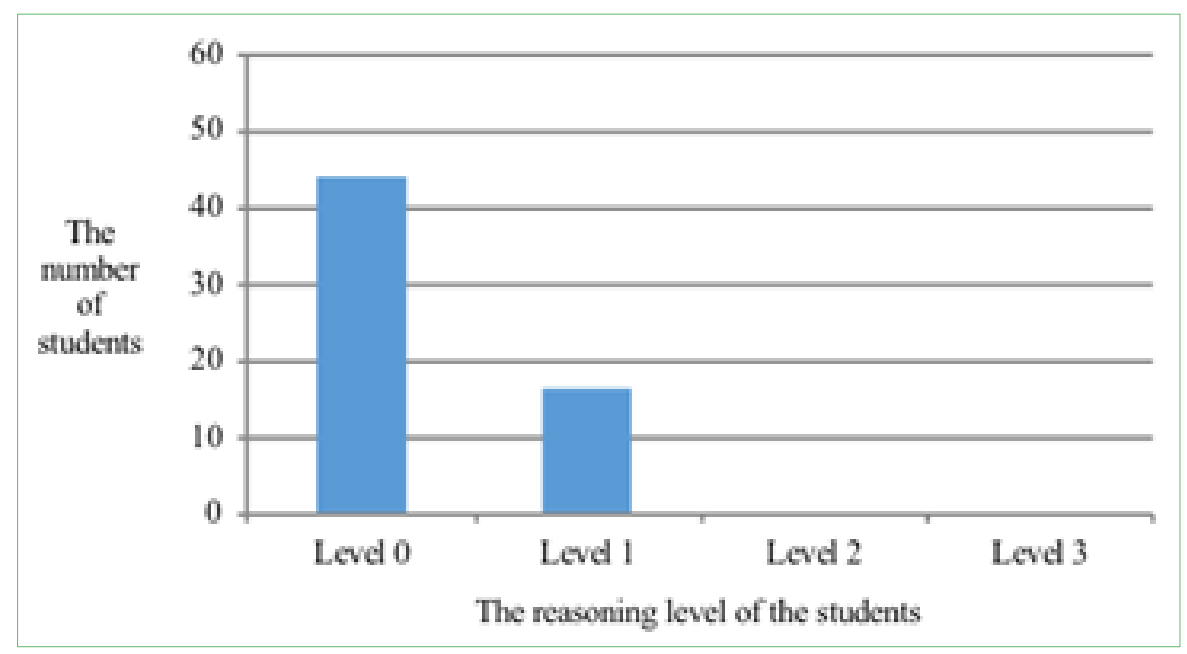

Figure 5. Scientific reasoning performance of students for the fourth question

Table 5. A student's answers to the fourth question and levels of reasoning

\begin{tabular}{llc}
\hline Question 5 & Example Answer & Reasoning Level \\
\hline $\begin{array}{l}\text { Kerem is stretching the bow. The force is not applied to Kerem in any way, but is applied to the } \\
\text { bow. }\end{array}$ & Level 0 \\
\hline $\begin{array}{l}\text { When Kerem opens the bow, the force affects him, because the bow is stretched, the force also } \\
\text { affects the bow. }\end{array}$ & Level 1 \\
\hline $\begin{array}{l}\text { The force of the bow affects Kerem and the force of Kerem also affects the bow. The forces are } \\
\text { opposite. }\end{array}$ & Level 2 \\
\hline There is no student at this level. & Level 3 \\
\hline
\end{tabular}




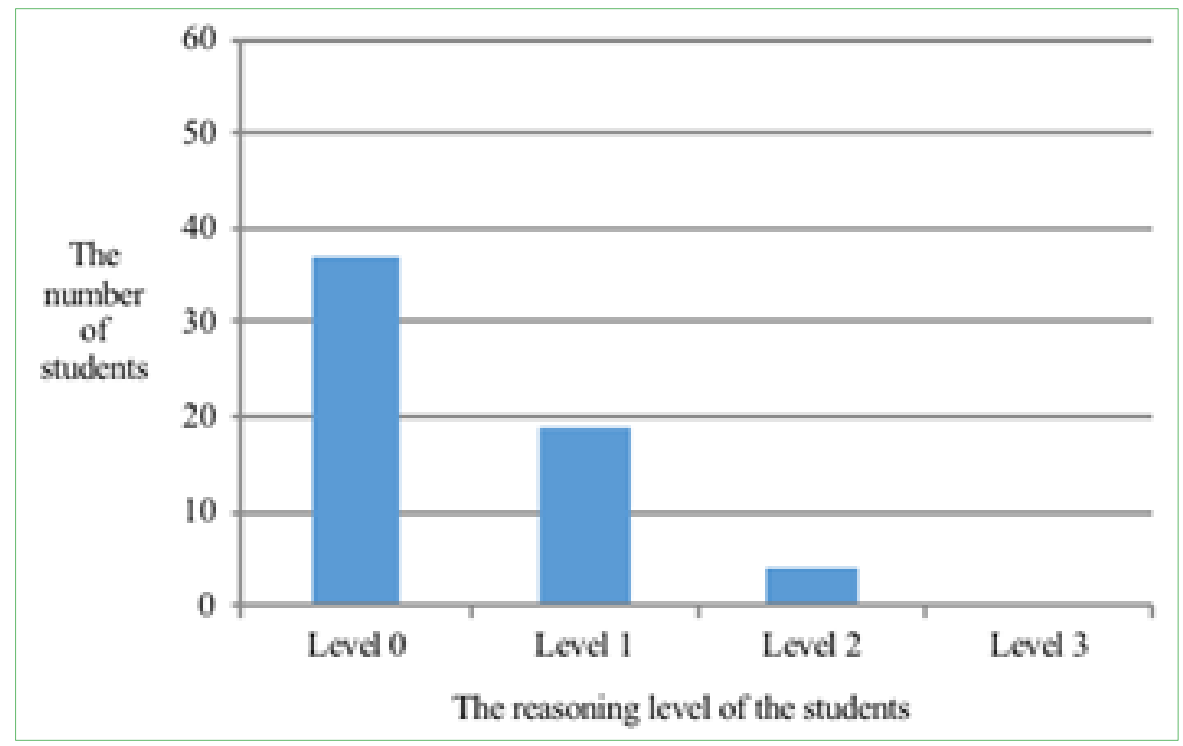

Figure 6. Scientific reasoning performance of students for the fifth question

Table 6. A student's answers to the fifth question and levels of reasoning

\begin{tabular}{llc}
\hline Question 5 & Example Answer & Reasoning level \\
\hline $\begin{array}{l}\text { It would be ridiculous to have all the appliances in the house working at the same time, so I think } \\
\text { that is why they are installed in parallel. }\end{array}$ & Level 0 \\
\hline $\begin{array}{l}\text { When the power is cut off at one place, it is installed in parallel in order not to interrupt at the other } \\
\text { place. }\end{array}$ & Level 1 \\
\hline There is no student at this level. & Level 2 \\
\hline There is no student at this level. & Level 3 \\
\hline
\end{tabular}

\subsection{Findings of Scientific Reasoning Skills of the Students in the Sixth Question}

Contrary to the first five two-stage questions, the sixth was a one-stage question. The students were asked: "In daily life, you hear a crackling sound when taking your sweater or shirt off. The reason for this phenomenon is the electrification of the objects. Why and how does this electrification event occur?" The statistical findings of this problem are shown in Figure 7. According to the findings in Figure 7, in this question, $61.7 \%$ of the students are at level $0,31.7 \%$ of them are at level 1 and $6.6 \%$ of them are at level 2 . In this question, there is no student carrying out scientific reasoning at level 3 .

\subsection{Findings of Scientific Reasoning Skills of the Students in the Seventh Question}

The 7th question was also a one-stage question. In this last question, the students were asked the following question: "Based on scientific data, explain how the electricity is formed, its structure and how it circulates in the electrical circuit by drawing a simple electrical circuit". The statistical findings of this question are shown in Figure 8. According to the findings in Figure 8, 15\% of the students are at level $0,36.7 \%$ of them at level 1 and $45 \%$ of them are at level 2 in this question. There is no student carrying out scientific reasoning at level 3 for this question. 


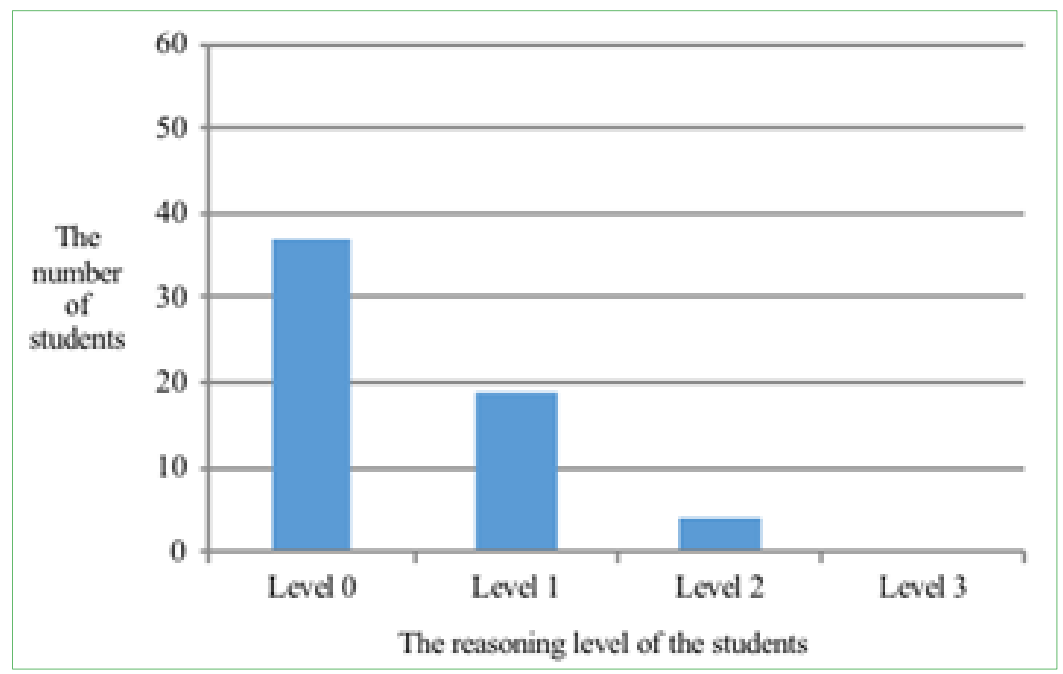

Figure 7. Scientific reasoning performance of students for the sixth question

Table 7. A student's answers to the sixth question and levels of reasoning



Figure 8. Scientific reasoning performance of students for the seventh question

Table 8. A student's answers to the seventh question and levels of reasoning

\begin{tabular}{lll}
\hline Question 7 & Example Answer & Reasoning level \\
\hline No drawing and also no other answers. & Level 0 \\
\hline Drawing is correct. No other answers. & Level 1 \\
\hline
\end{tabular}

Drawing is correct. Electricity occurs in the circuit as follows: bulb, battery switch, cable. When the switch presses the button, the battery works and the lamp lights up. What we call electricity is this: it occurs by vibrating. The electricity circulates in a simple circuit as follows: The place between the switch and the battery is a cable. When the button is pushed, the battery works and lights the bulb. It lights up the bulb as follows: No answer.

Drawing is correct. The electricity occurs in the circuit as follows: If the current consisting of the "+" pole is closed, it reaches the bulb and the bulb lights up. What we call electricity is this: electricity is an energy. This energy can be transformed into energies such as heat, motion and light in different ways. The electricity circulates in a simple circuit as follows: it moves from the "+" pole to the "-" pole. It lights up the bulb as follows: The conductor between the bulb and the battery carries the energy obtained from the + pole of the battery to the bulb. 


\section{Conclusions and Recommendations}

Scientific reasoning skills are necessary for all students trying to rationalize the World. Students process and respond to the information they collect through interaction with their environment. When solving a problem, the students need thinking and several cognitive activities that help them. Thus, scientific reasoning skills are currently seen as the necessary tool for the development of the students' conceptual and epistemological (what do I know and how do I know it) understanding of science and it is in the center of scientific applications [11, 19, 28, 29]. Within the scope of this study, it was intended to evaluate the scientific reasoning skills of the middle school 7 th grade students in the science course. When the findings acquired from the study were evaluated, it was seen that the reasoning performance of each student in the first five questions consisting of two parts was quite low. Their level of reasoning is at "Level 0" according to the rubric developed by the researcher. In other words, a conclusion revealing that the students could perform no scientific reasoning in any way on these questions and that they could not answer them was reached. Another important conclusion is that the students displayed a better performance only in the seventh question (the last question) when compared with the other six questions and that their reasoning levels were at "Level 2" for this question. These conclusions show that, in general, middle school students have difficulty in answering the questions related to science requiring scientific reasoning. The reason for the finding displaying a low level of scientific reasoning for the students may be the quality and the difficulty level of the questions. The questions in the rubric are mostly questions that are in the evaluation step, which is the highest step of the cognitive field according to Bloom's taxonomy. However, the evaluation step is a complex process including the combination of knowledge, comprehension, application, analysis and synthesis steps and the individual must accomplish knowledge, comprehension, application, analysis and synthesis steps to reach this step. To achieve this, the individual has to encounter high-level questions/adequate stimulants continuously. Otherwise, even though the student may have the knowledge, he/she will not be able to use it in reasoning processes. However, in the current Turkish educational system, the students cannot encounter these types of questions sufficiently during their academic education.

Writing an explanation by using scientific reasoning requires various information including a general understanding of scientific explanation (e.g. claim, evidence and reasoning) and a field-specific understanding of the content (e.g. what a chemical reaction is). Thus, there is a high correlation between scientific reasoning and science content information. In the present study, the reasons for the students' incapability in high-level scientific reasoning are the deficiencies in their information on science content. The lack of information on a subject is an obstacle for the students to present a scientific reasoning on this subject and this makes it difficult for them to carry out scientific reasoning on other subjects related to this subject. In addition to this, another finding of this study is that the traditional teaching of the science content information is not enough to develop the general reasoning skills of the students. The findings of my study reveal the significance of different information and support types in orienting the students towards complex questioning practices.

The findings obtained from the present study present some suggestions of focus to the researchers, teachers, and associated institutions and organizations for the development of the literature related to scientific reasoning. These suggestions are as follows:

- When the data and results obtained from the descriptive analysis of the scientific reasoning skills of the middle school 7 th grade students in the science course are considered, it is seen that the scientific reasoning skills of the middle school students are at a considerably low level. In accordance with this result, as projected also by the current reform documents in science education, the teachers play a role of utmost significance in developing the scientific reasoning skills of the students. Thus, teachers may be suggested to create environments where they can establish mutual interaction with their students, discuss concepts related to science and find the opportunity to think logically on various opinions related to science, that is, where they can support the scientific reasoning skills of the students. In other words, the students' learning status at school should be organized in accordance with their logical thinking processes and in a way to facilitate their scientific reasoning

- In this study, the scientific reasoning skills of the 7th grade students in the science course was investigated by creating a graded scoring key. This means that without implementing a teaching strategy that adopts a constructivist teaching approach, written data related to scientific reasoning were collected from the students in this study. In the other studies to be conducted in this field, it is considered that data collection after the implementation of teaching strategies by the researcher adopting constructivist teaching approach (such as argumentation, problem solving and inquiry) may be effective in uplifting the scientific reasoning skills of the students to higher levels because the surroundings in which the constructivist teaching approach is adopted are environments where active participation of all students is supported and where a collaborative learning environment is created and social interaction is increased. Furthermore, in the future studies, 
research on the effects of different teaching strategies such as argumentation, problem solving and inquiry on the students' scientific reasoning skills may be conducted with comparative studies.

- Development of scientific reasoning skills is a long-term process [42] and the students cannot be expected to perfect their scientific reasoning skills within a course subject, a course unit or a year. Hence, when developing a science syllabus, a teaching program that aims to develop the scientific reasoning skills of the students at every level of the education beginning from the pre-school period must be developed and practiced because the approach of the students to a situation or an event is established with the education given beginning from the first years of the elementary education.

- This study is a study conducted with the participation of the 7th grade students in a public middle school in Ankara. Similar studies may be conducted for the 7 th grade students in the public middle schools in other cities. Also, this study may be performed with 7th grade students from private middle schools and comparative research on the subject may be conducted.

- This study was conducted with middle school students. In the future studies, scientific reasoning levels of the students at different levels of education such as elementary school, high school, and undergraduate and graduate university degrees may be investigated.

- $\quad$ Scientific reasoning levels of the students may be researched by conducting long-term studies such as those lasting 2-3 years.

- $\quad$ This study may be conducted with gifted 7 th grade students and comparative studies may be carried out.

- $\quad$ - The present study adopted a descriptive research approach and it is a qualitative study. In the future studies, the findings obtained by qualitative research methods related to scientific reasoning levels of the 7th grade students may be supported by using quantitative research methods. More in-depth and more reliable data may be obtained this way. Also, it may be suggested to put more emphasize on mixed research methods in the determination of scientific reasoning levels.

- In this study, the scientific reasoning skills of the students were not problematized according to sex. In the future studies, research on whether scientific reasoning of the students differs according to sex may be done.

- The teachers may be shown how to support the reasoning skills in students better by giving them in-service education courses, seminars and conferences that may contribute to the development of the scientific reasoning levels of students.
- The rubric used with the purpose of determining the scientific reasoning skills of the 7 th grade students may be applied to the students both at the beginning and at the end of the term and the change in the scientific reasoning levels of the students may be observed.

- The researchers making studies in this field may be suggested to investigate the relationship between the academic achievement points of the middle school students in the science course and their scientific reasoning skills

- $\quad$ The rubric developed within the scope of this study may be used in various studies conducted with the aim of determining the scientific reasoning levels of the middle school students.

\section{REFERENCES}

[1] Akerson, V. L., \& Volrich, M. (2006). Teaching nature of science explicitly in a first grade internship setting. Journal of Research in Science Teaching, 43(4), 377-394.

[2] Aslanoğlu, A. E., \& Kutlu, Ö. (2003). Öğretimde sunu becerilerinin değerlendirilmesinde dereceli puanlama anahtarı (rubric) kullanılmasına ilişkin bir araştırma. Ankara University Journal of Faculty of educational Sciences, 36(1-2), 25-36.

[3] Atılgan, H., Kan, A., \& Doğan, N. (2007). Eğitimde ölçme ve değerlendirme. Ankara: Anı Yayıncılık.

[4] Bransford, J. D., Brown, A. L., \& Cocking, R. R. (2000) How people learn: Brain, mind, experience, and school. Washington, DC: National Academy Press.

[5] Burbules, N. C., \& Linn, M. C. (1988). Response to contradiction: Scientific reasoning during adolescence. Journal of Educational Psychology, 80(1), 67-85.

[6] Büyükkıdık, S. (2012). Problem çözme becerisinin değerlendirilmesinde puanlayıcılar arası güvenirliğin klasik test kuramı ve genellenebilirlik kuramına göre karşıllaştırılması. Unpublished master thesis, Hacettepe University, Ankara.

[7] Büyüköztürk, Ş., Çakmak, E. K., Akgün, O. E., Karadeniz, S., \& Demirel, F. (2013). Bilimsel araştırma yöntemleri $\left(15^{\text {th }}\right.$ Ed.). Ankara: Pegem Akademi.

[8] Chiappetta, E. L., Koballa, T. R., Collette, A. T., \& Collette, A. T. (1998). Science instruction in the middle and secondary schools. Upper Saddle River, N.J: Merrill.

[9] Çalik, M., Ayas, A., \& Coll, R. K. (2007). Enhancing pre-service elementary teachers' conceptual understanding of solution chemistry with conceptual change text. International Journal of Science and Mathematics Education, 5(1), 1-28.

[10] Driver, R., Leach, J., Millar, R., \& Scott, P. (1996). Young people's images of science. Buckingham, UK: Open University Press. 
[11] Driver, R., Newton, P., \& Osborne, J. (2000). Establishing the norms of scientific argumentation in classrooms. Science Education, 84(3), 287-312.

[12] Goodrich-Andrade, H. (2005). Teaching with rubrics: The good, the bad, and the ugly. College Teaching, 53(1), 27-31.

[13] Gotwals, A. W., Songer, N. B., \& Bullard, L. (2012). Assessing students' progressing abilities to construct scientific explanations. In A. C. Alonzo \& A. W. Gotwals (Eds.), Learning progressions in science (pp. 183-210). The Netherlands: Sense Publishing.

[14] Greenhoot, A. F., Semb, G., Colombo, J., \& Schreiber, T. (2004). Prior beliefs and methodological concepts in scientific reasoning. Applied Cognitive Psychology, 18(2), 203-221.

[15] Hafner, J., \& Hafner, P. (2003). Quantitative analysis of the rubric as an assessment tool: An empirical study of student peer-group rating. International Journal of Science Education, 25(12), 1509-1528.

[16] Halonen, J. S., Bosack, T., Clay, S., McCarthy, M., Dunn, D. S., Hill IV, G. W., ... \& Whitlock, K. (2003). A rubric for learning, teaching, and assessing scientific inquiry in psychology. Teaching of Psychology, 30(3), 196-208.

[17] Hogan, K. (2002). Small groups' ecological reasoning while making an environmental management decision. Journal of Research in Science Teaching, 39(4), 341-368.

[18] Hogan, K., \& Fisherkeller, J. (2005). Dialogue as data: Assessing students' scientific reasoning with interactive protocols. In J. J. Mintzes, J. H. Wandersee, \& J. D. Novak (Eds.), Assessing science understanding: A human constructivist view (pp. 95-127). Burlington, MA: Elsevier Academic Press.

[19] Hogan, K., \& Maglienti, M. (2001). Comparing the epistemological underpinnings of students' and scientists' reasoning about conclusions. Journal of Research in Science Teaching, 38(6), 663-687.

[20] Holyoak, K.J., \& Morrison, R.G. (in press). Thinking and reasoning: A reader's guide. In K. J. Holyoak \& R. G. Morrison (Eds.), Oxford Handbook of Thinking and Reasoning. New York: Oxford University Press.

[21] Kenyon, L., \& Reiser, B. J. (2006, April). A functional approach to nature of science: Using epistemological understandings to construct and evaluate explanations. Paper presented at the annual meeting of the American Educational Research Association (AERA), San Francisco, CA.

[22] Klaczynski, P. A. (2000). Motivated scientific reasoning biases, epistemological beliefs, and theory polarization: A two-process approach to adolescent cognition. Child Development, 71(5), 1347-1366.

[23] Klahr, D., \& Dunbar, K. (1988). Dual space search during scientific reasoning. Cognitive Science, 12(1), 1-48.

[24] Kolomuç, A., \& Tekin, S. (2011). Chemistry teachers' misconceptions concerning concept of chemical reaction rate. Eurasian Journal of Physics and Chemistry Education, 3(2), 84-101.

[25] Koslowski, B. (2012). Inference to the best explanation (IBE) and the causal and scientific reasoning of nonscientists. In R.
W. Proctor \& E. J. Capaldi (Eds.), Psychology of science: Implicit and explicit processes (pp. 112-136). New York, NY, US: Oxford University Press.

[26] Krajcik, J., McNeill, K. L., \& Reiser, B. J. (2008). Learninggoals-driven design model: Developing curriculum materials that align with national standards and incorporate project-based pedagogy. Science Education, 92(1), 1-32.

[27] Kuhn, D. (1989). Children and adults as intuitive scientists. Psychological Review, 96(4), 674-689.

[28] Kuhn, D. (1993). Science as argument: Implications for teaching and learning scientific thinking. Science Education, 77(3), 319-337.

[29] Kuhn, D. (2002). What is scientific thinking, and how does it develop? In U. Goswami (Ed.), Handbook of childhood cognitive development. Oxford, England: Blackwell.

[30] Kuhn, D. (2005). Education for thinking. Cambridge, MA: Harvard University Press.

[31] Kuhn, D., Amsel, E., O'Loughlin, M., Schauble, L., Leadbeater, B., \& Yotive, W. (1988). The development of scientific thinking skills. San Diego, CA: Academic Press.

[32] Kuhn, L., \& Reiser, B. (2005, April). Students constructing and defending evidence-based scientific explanations. Paper presented at the annual meeting of the National Association for Research in Science Teaching (NARST), Dallas, TX.

[33] Lawson, A. E. (2005). What is the role of induction and deduction in reasoning and scientific inquiry?, Journal of Research in Science Teaching, 42(6), 716-740.

[34] Lawson, A. E., Banks, D. L., \& Logvin, M. (2007). Selfefficacy, reasoning ability, and achievement in college biology. Journal of Research in Science Teaching, 44(5), 706-724.

[35] Lederman, N. G. (2007). Nature of science: Past, present, and future. In S.K. Abell, \& N.G. Lederman, (Editors), Handbook of research in science education (pp 831-879). Mahwah, New Jersey: Lawrence Erlbaum Publishers.

[36] McNeill, K. L., Lizotte, D. J., Krajcik, J., \& Marx, R. W. (2006). Supporting students' construction of scientific explanations by fading scaffolds in instructional materials. The Journal of the Learning Sciences, 15(2), 153-191.

[37] Miles, M. B., \& Huberman, A. M. (1994). Qualitative data analysis: An expanded sourcebook ( $2^{\text {nd }}$ ed.). Thousand Oaks, CA: Sage.

[38] Millar, R., \& Osborne, J. F. (Eds.). (1998). Beyond 2000. Science education for the future. $A$ report with ten recommandations. London, UK: King's College London.

[39] Moskal, B. M. (2000). Scoring rubrics: What, when and how?, Practical Assessment, Research \& Evaluation,7(3), $1-5$.

[40] National Research Council [NRC]. (2012). A framework for K-12 science education: Practices, crosscutting concepts, and core ideas. Washington, DC: The National Academies Press.

[41] Novak, A. M., \& Treagust, D. F. (2013, April). Adjusting claims as new evidence emerges: Do students incorporate 
new information into their scientific explanations. Paper presented at the annual meeting of National Association for Research in Science Teaching (NARST), Puerto Rico.

[42] Osborne, J., Erduran, S., \& Simon, S. (2004). Enhancing the quality of argumentation in school science. Journal of Research in Science Teaching, 41(10), 994-1020.

[43] Overton, W. F. (1990). Competence and procedures: Constraints on the development of logical reasoning. In W. F. Overton (Ed.), Reasoning, necessity, and logic: Developmental perspectives. Hillsdale, NJ: Lawrence Erlbaum Associates.

[44] Quitadamo, I. J., \& Kurtz, M. J. (2007). Learning to improve: Using writing to increase critical thinking performance in general education biology. CBE-Life Science Education, $6(2), 140-154$.

[45] Reif, F., \& Larkin, J. H. (1991). Cognition in scientific and everyday domains: Comparison and learning implications. Journal of Research in Science Teaching, 28(9), 733-760.

[46] Samarapungavan, A. (1992). Children's judgments in theory choice tasks: Scientific rationality in childhood. Cognition, 45(1), 1-32.

[47] Sandoval, W. A., \& Reiser, B. J. (2004). Explanation-driven inquiry: Integrating conceptual and epistemic scaffolds for scientific inquiry. Science Education, 88(3), 345-372.

[48] Schauble, L., Glaser, R., Duschl, R. A., Schulze, S., \& John, J. (1995). Students' understanding of the objectives and procedures of experimentation in the science classroom. The Journal of the Learning Sciences, 4(2), 131-166.

[49] Schwartz, R. S., Lederman, N. G., \& Crawford, B. A. (2004). Developing views of nature of science in an authentic context: An explicit approach to bridging the gap between nature of science and scientific inquiry. Science Education, $88(4), 610-645$.

[50] Stanovich, K. E., \& West, R. F. (1997). Reasoning independently of prior belief and individual differences in actively open-minded thinking. Journal of Educational Psychology, 89(2), 342-357.

[51] Tytler, R., \& Peterson, S. (2003). Tracing young children's scientific reasoning. Research in Science Education, 33(4), 433-465.

[52] Tzou, C. T. (2006, April). Characterizing teachers' support of constructing scientific explanations from a discourse perspective. Paper presented at the annual meeting of the American Educational Research Association (AERA), San Francisco, CA.

[53] Valanides, N. (1997). Formal reasoning abilities and school achievement. Studies in Educational Evaluation, 23(2), 169-185.

[54] Varelas, M. (1996). Between theory and data in a Seventhgrade science class. Journal of Research in Science Teaching, 33(3), 229-263.

[55] Vass, E., Schiller, D., \& Nappi, A. J. (2000). The effects of instructional intervention on improving proportional, probabilistic, and correlational reasoning skills among undergraduate education majors. Journal of Research in Science Teaching, 37(9), 981-995.
[56] Williams, W. M., Papierno, P. B., Makel, M. C., \& Ceci, S. J. (2004). Thinking like a scientist about real-world problems: The Cornell Institute for research on children science education program. Journal of Applied Developmental Psychology, 25(1), 107-126.

[57] Zeineddin, A., \& Abd-El-Khalick, F. (2010). Scientific reasoning and epistemological commitments: Coordination of theory and evidence among college science students. Journal of Research in Science Teaching, 47(9), 1064-1093.

[58] Zimmerman, C., Raghavan, K., \& Sartoris, M. (2003). The impact of the MARS curriculum on students' ability to coordinate theory and evidence. International Journal of Science Education, 25(10), 1247-1271.

[59] Zohar, A., \& Nemet, F. (2002). Fostering students' knowledge and argumentation skills through dilemmas in human genetics. Journal of Research in Science Teaching, 39(1), 35-62. 